\title{
PROBLEMS OF HORSE BREEDING DEVELOPMENT IN PEASANT FARMS IN THE SOUTH OF UKRAINE (1860s - 1910s)
}

\author{
Nataliia Chernikova \\ Doctoral Student, Ph.D. in History, Oles Honchar Dnipro National University, Ukraine \\ e-mail: chernikova.natka@gmail.com, orcid.org/0000-0002-5470-0622
}

\section{Summary}

The paper analyzes the state of development of horse breeding in the peasant farms of the South of Ukraine in the post-reform period. The dynamics of quantitative development of the industry is traced. The relationship between the increase in the number of horses and the growth of the population and farms in the region has been established. It is proved that the peasants were the main owners of horses. The thesis about the "peasant" nature of horse breeding in the South of Ukraine is argued. It was found that the use of work horses in farming contributed to the development of the industry. Government measures to encourage the development of local horse breeding have been traced: creation of a network of state stables and copulation stations in order to improve the quality characteristics of work horses, holding exhibitions, etc. The price level and place of equestrian trade in the region are analysed. Attention is focused on the lack of "entrepreneurial" horse breeding in the region, the excessive situational nature of the horse trade among the peasants, and its local centers - fairs were clarified. The reasons and factors that led to the decline of the industry in the South of Ukraine are analyzed: high cost, low level of knowledge and culture on keeping, care, breeding horses, etc.

Keywords: horse trade, fairs, workhorse, agricultural entrepreneurship, farmer, state stables.

DOI: https://doi.org/10.23856/4504

\section{Introduction}

During the $19^{\text {th }}$ cent. the Russian Empire ranked first among European countries in the number of horses: in 1882 there were more than 21 million of them. An important role in the development of horse breeding was played by the region of Southern Ukraine ${ }^{1}$, where herds of wild horses grazed on the endless steppes for many centuries. Not surprisingly, the local population "domesticated" and increasingly used horses on the farm. Therefore, Ekaterinoslav, Tavriya and Kherson provinces had advantages among most others in breeding various types and breeds of horses due to the presence of large pastures, fresh fodder, warm dry climate and more.

It is difficult to even imagine how many modern technical and technological means are involved in the performance of those functions that two centuries ago relied on ordinary horses! During the $19^{\text {th }}$ century they remained the main means of transportation in both rural and urban areas. The army, in particular the military cavalry troops, could not do without them. Horses also served as a means of transporting goods, a transfer for postal items. In landed estates, thoroughbred horses, in addition to purely economic, had a leisure purpose (as a hobby) and were kept for races, exhibitions, etc.

1 Lands of the South of Ukraine included Ekaterinoslav, Kherson and Tavriya provinces, which at that time were part of the Russian Empire. 
However, from the 1860s radical changes took place in horse breeding: along with the preservation of traditional trends, a new one developed - agricultural, or peasant, which became decisive in the development of the industry until 1917. This was due to the formation of capitalist relations in the agricultural sector of the economy and the formation of peasant farming in the South of Ukraine.

The fact is that the abolition of serfdom in 1861 in the Russian Empire led to a significant increase in the number of peasant farms. In the Southern Ukrainian provinces with a mild temperate climate, vast land areas and chernozem soils, land was plowed rapidly and the transition to commodity grain production. If wealthy landowners switched to the use of agricultural machinery, the peasants actively used horses to cultivate the land, as a traction force in agricultural work. Therefore, horses were of great importance for peasant farms as "livestock", without which it was impossible to grow grain. In addition, no domestic animal enjoyed such respect among the peasants as the horse. "A good owner does not have a bad horse," said the proverb.

As we can see, horse breeding as a branch of economy due to favorable climatic conditions, the presence of historical experience, the growth of demand had all the chances for development. However, in the words of the famous historian A. Skalkowskij, “... both breeding and trade in horses were at a level much lower than that which nature itself assigned to the region" (Skalkovskij, 1853: 377-378). Therefore, the purpose of this study is to clarify the peculiarities of the development of peasant horse breeding in southern Ukraine and the reasons for the decline of this promising industry in the post-reform period. To achieve it, a quantitative analysis of horse breeding was carried out, the nature and specifics of the development of the industry in peasant farms, the directions of government policy on the development of the industry and the peculiarities of the horse trade in the region were clarified. The research methodology is based on the principles of objectivity, systematization and historicism with the use of general scientific and special-historical methods: historical-genetic, historical-comparative, descriptive, historical-typological, system-structural.

\section{Quantitative analysis of the state of horse breeding in the South of Ukraine}

In the early 1860 s, horse breeding in the South of Ukraine was in a state of partial decline, or at least stagnation: "did not prosper", as contemporaries said (Bystrickij, 1889: 204). In the Tavriya province, the Crimean War of 1853-1856 and the expulsion of the Tatars caused significant losses of horses in 1860-1862, which was caused by competition with the Don region, where horse breeding was developing rapidly. In some farms Kherson peasants preferred to use oxen for field work, so the demand for horses was quite limited. The fact is that the local breeds of steppe horses that dominated the Kherson region were small, suitable for light cavalry and light field work, so they were in demand only among a few German colonists, Jews and burghers.

An important reason for the reduction of the role of animal husbandry, including horse breeding, in the South of Ukraine in the post-reform years was the reformatting of the agricultural sector of the economy. The rapid population of the region, the growth of demand and prices for grain crops, the plowing of land due to the reduction of pasture areas have led to the sociability and dominance of entrepreneurial grain production over livestock. It is important that in the economic use of unploughed steppe lands, large landowners preferred commodity-oriented merino sheep, which brought owners higher and guaranteed profits. 
However, the rapid increase in the number of peasant farms focused on agricultural activities has increased consumer interest in horses as "livestock". In 20 years (from 1860 to 1880) the total number of horses in the Kherson region has more than tripled, and in Tavriya - 1.5 times (Kherson Provincial Statistical Committee, 1863: 108-111; Verner, 1889: IV, 4; Zertsalov, 1892: 5).

During the 1880 s and 1890 s, the number of horses in the South of Ukraine continued to grow steadily - by an average of $38 \%$ compared to the previous period. Characteristically, this process was accompanied by a decrease in the number of farms that did without horses: in 1896 there were $30 \%$, ie $6.3 \%$ less than in 1882 (Dubenskij, 1903: 225). Such positive dynamic processes in the quantitative growth of horse breeding were observed in the South of Ukraine before the First World War. The available fluctuations of quantitative indicators in the direction of reduction in some years, as a rule, depended on the yield, climatic features, epidemiological diseases that lurked in the horses in a given year. In addition, it should be borne in mind that in the statistical reports of different departmental institutions, due to the different criteria for collecting information, the indicators differed slightly.

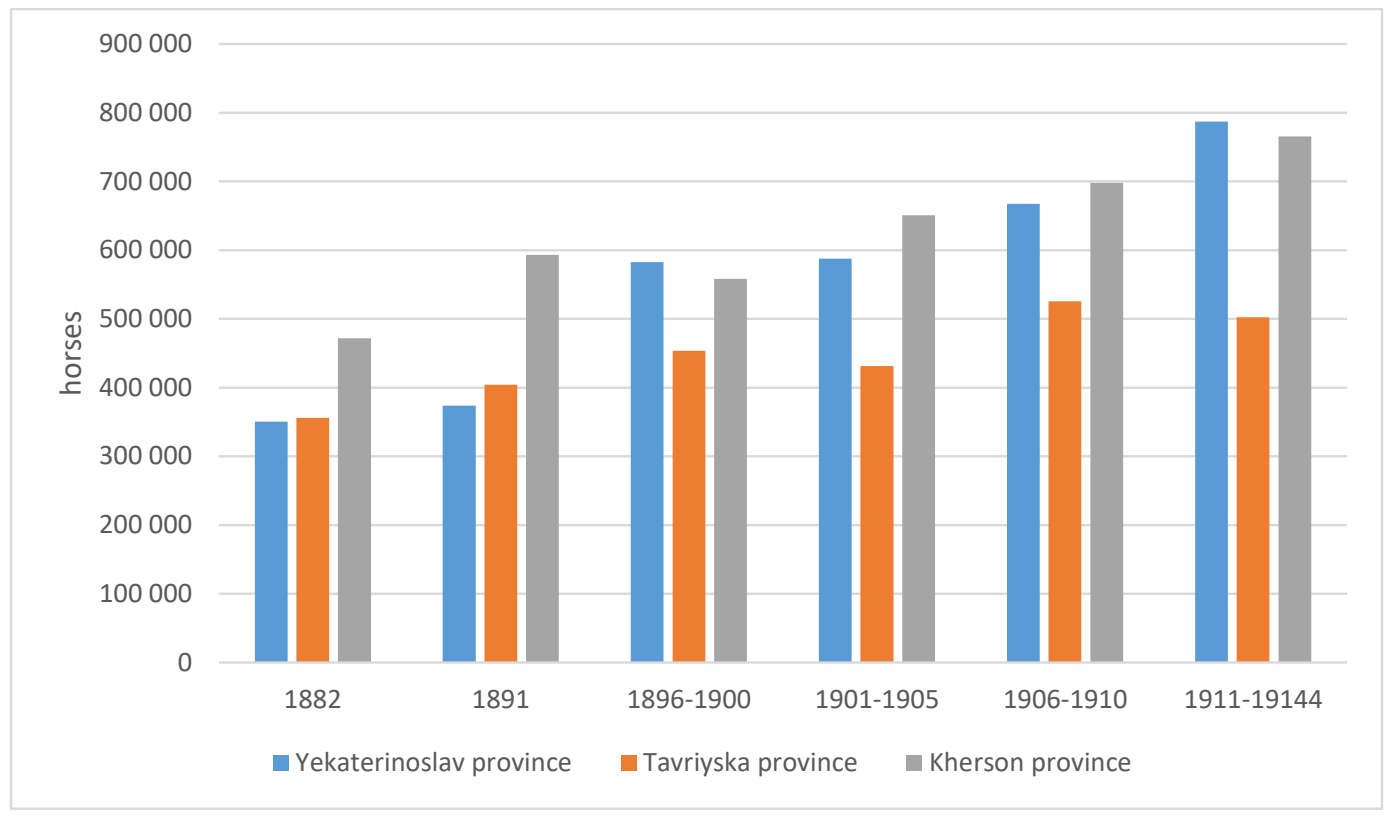

\section{Graph 1. Dynamics of growth in the number of horses in the Southern Ukrainian provinces}

Source: Dubenskij, 1903: 225; Veterinarnoe upravlenie Ministerstva Vnutrennih Del, 1915a: 1-4; Veterinarnoe upravlenie Ministerstva Vnutrennih Del, 1915b: 1-5

In the late $19^{\text {th }}$ cent. increase of horse herd was driven by the objective laws of economic expediency, relating primarily to peasant farms, which usage of horses was gaining momentum. Less farmers used oxen preferred for field operations and replaced them with horses. Economist A.A. Kaufman explained it as follows: "The main disadvantage of bulls - slowness and weakness compared to horses", so "when calculating a pair of bulls is usually equated to one horse", meanwhile, "a middle-class bull ... is more expensive than the average peasant horse" 
(Kaufman, 1917: 144-332). Thus, at the beginning of the $19^{\text {th }}$ cent. the horse was the main type of working cattle. Indicative in this context are the indicators for Elisavetgrad district ${ }^{2}$ where in the first post-reform 20 years the number of horses increased by 6.1 times, while livestock cattle - only twice (Zertsalov, 1892: 7).

It is worth mentioning that the distribution of horses by counties also differed in quantitative heterogeneity from 27 thousand in Slavic-Serbian district to 104 thous. at the Olexandrivsk district (Ekaterinoslav), from 6 thous. in Yalta to 151 thous. in Melitopol district (Tavriya) (Dubenskij, 1903: 226). This discrepancy was due primarily to the number of peasant farms and their economic orientation in each district. For example, in Yalta farmers engaged mainly tobacco, gardening and viticulture using human labour, therefore the horse farm were not needed (Bojko, 2013: 110-111). Instead, there were more horses in those regions where grain farming developed.

It should be noted that the South of Ukraine was also characterized by a high concentration of horses relative to the population. In 1891-1896, for every 100 people, there were on average 29 horses: 25, 35 and 28 in Ekaterinoslav, Tavriya and Kherson provinces, respectively (Dubenskij, 1903: 228). Quite strong performance, particularly in Tavriya province, is due to the preservation of the region tradition herd horses, but the level of availability of horses and subjected to reduction even here, because even at the beginning of 1880s it was 45.1. As a conclusion, people's provision of horses decreased compared to increasing population. Therefore, the increase in horses in the region was explained only by the increase in agricultural holdings.

As noted, the owners of the horses were landowners, peasants and burghers. In the first half of the $19^{\text {th }}$ cent. maintenance of horses was carried out mainly by landowners (Giber-von-Greifenfels, 1897; Volos, 2012: 99-102; Zaderejchuk, 2010). But after the abolition of serfdom, the peasants took over this initiative. In fact, as early as the $1880 \mathrm{~s}$ the ratio was established, which did not change significantly until 1914. This distribution of horses between peasants and private owners remained almost unchanged, ranging from 80-90\% and 10-20\% respectively (Glavnoe Upravlenie Konnogo Zavodstva, 1884: 66; Centralnyj Statisticheskij Komitet Ministerstva Vnutrennih Del, 1901: 5; Centralnyj Statisticheskij Komitet Ministerstva Vnutrennih Del, 1914: 10, 16, 35, 52). In the Southern Ukraine distribution did not differ from most provinces of Russia: among households, $82.5 \%$ were peasants horse households, who like to focus on $3 / 4$ horses of the region, and a $11,5 \%$ of the landed households who contained $1 / 5$ horses.

It is significant that peasants outnumbered private owners in the number of horses, even among multi-horse farms. So it is entirely clear that the development of horse breeding in the South of Ukraine is largely dependent in the state of peasant's farms. Because of farming being in both the material and the social aspect as heterogeneous, we should pay attention to the distribution of horses among the peasantry. It is important that the number of horses was strictly determined by the level of economic needs of the owner and, accordingly, testified to the volume and direction of management. Keeping horses was too expensive for ordinary peasants, so the number of horses could be judged on the property status of the family. For example, farms with 1 horse can be classified as semi-proletarian, farms with 2-3 horses - to medium. Instead, owners who had 4 or 5 horses were considered as wealthy, and having 6 or more horses meant being involved in farming entrepreneurship (Ostrovskij, 2014: 66).

2 Elisavetgrad district of Kherson province was one of the centers of horse breeding in the South of Ukraine. 

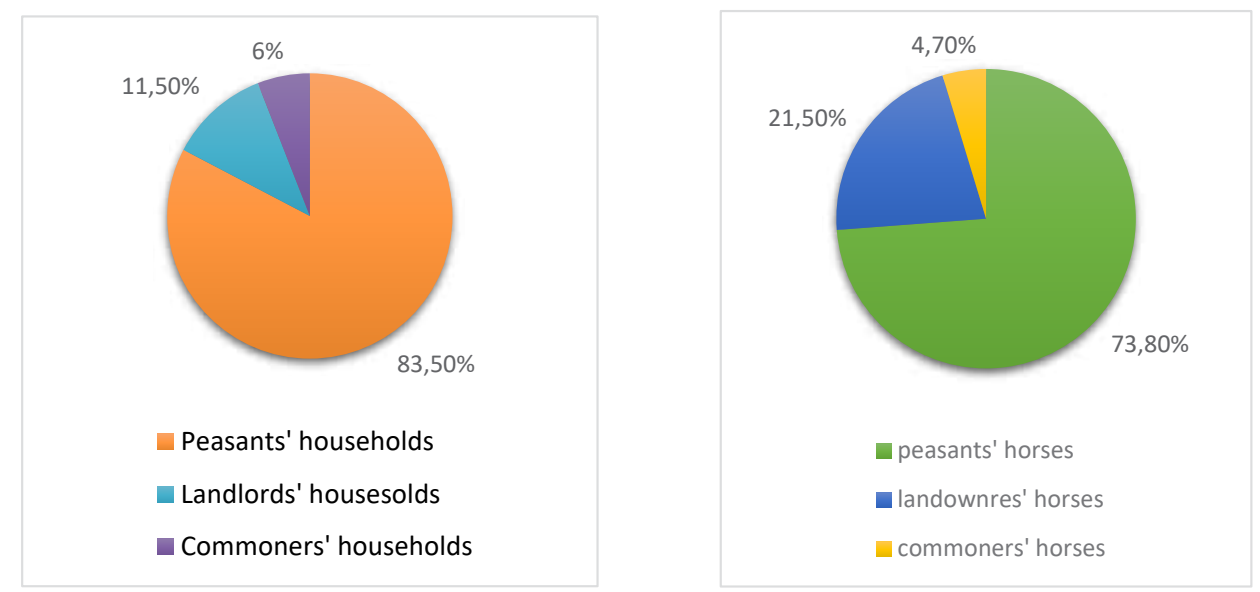

\section{Graph $2 \&$ Graph 3. The ratio of horse farms (by social status of owners) in the (left) \& Distribution of horses between farms (by social status of owners) (right) in the South of Ukraine}

Source: Dubenskij, 1903: 226, 227

In 1888-1891 there were $19 \%$ of wealthy and farm peasant farms (which had more than 4 horses) while the average in Russia was $11 \%$. ${ }^{20}$ The share of horse concentration in business farms was $35.6 \%$, and in the wealthy $-21.1 \%$. Compare with those of other provinces, where businesses owned more than half the horses $(16.7 \%)$, while the proportion of horses with wealty peasants were almost identical (20.7\%) (Centralnyj Statisticheskij Komitet Ministerstva Vnutrennih Del, 1891; Centralnyj Statisticheskij Komitet Ministerstva Vnutrennih Del, 1894). This confirms the fact of high development of grain entrepreneurship in farms in the in the Southern region.

In the 1890 s $1 / 3$ of households provinces of Southern Boulevard and secured and more than 4 horses, that fig and inventory entrepreneurial orientation, and more than $1 / 2$ held 2-3 horses allowed to meet its own household needs (Dubenskij, 1903: 227).

\section{Quality state of horse breeding of peasant's households in the South of Ukraine}

These quantitative data convincingly show that a characteristic feature of the development of horse breeding was its peasant character. So let's try to find out the quality of the industry, which is now concentrated in the hands of peasants.

The so-called "simple" or "farm" breeding, which involved the use of animals in as draft animals working with or in agricultural activities, was common only in farms. On it rested tiller production: export of fertilizer, plowing, harrowing, sowing laying, transporting harvest and so on. Workers set in motion agricultural machines: seeders, harvesters, threshers, fans, sorting machines. Cartage ensures the supply of livestock feed (transport hay, straw) supply of fuel and building materials. With its help agricultural products were delivered to local markets, brought up to railway stations, river's piers, sea's ports. Horses as a traction force were used in industry and construction. With their help postal communication and transportation of passengers was carried out. By the way, no other animal of pre-revolutionary Russia and in many other countries was as honoured as a horse. 
However, unfortunately the villagers hardly concerned the issue of improving its quality characteristics. Typical working peasants horses characterized as small in stature, weak physique, differentiation of forms (large or small head, big flabby belly, weakness, etc.). For example, the Ekaterinoslav peasants were dominated by steppe horses of the Little Russian breed, which were not adapted to the hardships of their long-term work, while the Taurian peasants were dominated by horses of the South Russian or Crimean breed. Instead, working horses in the Kherson region, which also came from local breeds, were more endurable. However, the conditions of their keeping obviously did not contribute to further improvement (or at least preservation) of positive traits. As already mentioned, in the South of Ukraine there was a process of intensive plowing of land and the transition to commodity grain production, which was accompanied by a significant increase in prices for the purchase and lease of land. This negatively affected the development of horse breeding, causing shortages of pastures and, consequently, fodder for satisfactory livestock. After all, an ordinary peasant, who had (unlike landowners) a limited plot of land, used it to the maximum for growing wheat, oats, barley, and so on.

So where did the peasants graze the horses? Almost throughout the year the horses were in the open air on grass and didn't have special care from owner. The exception was working cattle, which received better nutrition and were provided with grain during field work. In the summer horses were sent to the public grazing, where each owner had personally taken care of the problem of grazing. Sometimes horses were given for grazing to private owners for 4-9 rubles or subject to working off. Winter diet of cattle consisted of straw and partly hays as well. If the owners were unable to feed the horses, they gave it to private owners for feeding on cash terms - 10-15 rubles or working pay (Zertsalov, 1892: 30).

The rapid growth of the population and the fragmentation of peasant families required, accordingly, a proportional growth of working cattle, which took place extensively. In the most unfavorable position were foals, which the owners began to take care of only from the moment of operation, which started too early - often from one year, and in field work - from 2-3 years. Often the peasants preferred to buy not adult horses, but foals, which were much cheaper, which were immediately used on the farm. This obviously did not contribute to the efficiency of livestock, and, moreover, led to population degradation. After all, the peasants did not take care of the problem of reproduction and choice of the stallion. Unfortunately, they rarely turned to local landlords who kept thoroughbred horses to improve the breed. Noting the lack of control in the breeding of horses and the lack of ideas about the importance of breeding stallions for offspring, veterinarian Zertsalov wrote that "communities do not care about getting good foals, they do not have good producers" (Zertsalov, 1892: 29).

Among the problems that befell on local horse breeding and negatively affected in the development of the industry, we also note of the disease and horse-stealing. Among the diseases that most often affected horses in Southern Ukraine were foot-and-mouth disease, scabies and hoof diseases, as well as (except in Ekaterinoslav region) a variety of anthrax, which caused enormous damage to owners. For example, at the end of 1880s Elisavetgrad owners lost from 1,5 to 2,3\% of horses (Dubenskij, 1903: 241; Zertsalov, 1892: 30).

Horse theft was common here and caused significant damage. Peasants tried to combat this phenomenon by various means: from exile to Siberia on the verdict of the communities to bonuses for the detention of horse thieves, but the result was meager. As a result, the peasants used a very unusual form of protection on the principle: "the worse the horse, the less likely it is to be abducted" (Glavnoe Upravlenie Konnogo Zavodstva, 1884: 114, 132; Markov \& Dubenskij, 1903: 238). Undoubtedly, this had a negative effect on the quality of working 
horses. Surprisingly, however, in the settlements of German colonists cases of theft of horses almost never happened that contemporaries attributed to exemplary solidarity and good faith duties of night watchmen, "to searching for stolen horse and thieves whole congregation of colonists rises to their feet as one man" (Glavnoe Upravlenie Konnogo Zavodstva, 1884: 132). Therefore, the experience of German settlers proved that the problem of horse theft could be solved by concerted action, rather than careless treatment of horses!

Unfortunately, this attitude to horse led on to massive degradation of peasant horses. The vast majority of horses in peasant farms, "does not belong to a particular breed and no different good qualities about except perhaps undemandingness and the ability to get used with the worst living conditions" (Chirvinskij, 1902: 61).

However, it should be noted that exceptions did take place. For example, wealthy owners (farmers, colonists, tradesmen) of Kherson, particularly from areas with developed horse breeding, were more concerned with controlled breeding hardy working horses and turned to horse breeders. Most popular were horses of Elisavetrad and Alexandriya districts, which came by horses landed factory, improved by manufacturers of local plant stable (Dubenskij, 1903: 236-237). Some exceptions were also horses on farms of German colonists that had exceptive stature and strength through good feeding and care. In caring for cattle, they used the Ukrainian proverb "Do not feed a horse with a whip, but feed with oats". To improve the breed each community bought stallion-producers (not rarely for 500-600 rub.), and kept the females for breeding of improved breeds (Dubenskij, 1903: 235-236, 238). It is noteworthy that German villagers have been using the mixed breed horses for all field work, so they no longer cared about the physical condition of livestock. Instead, the vast majority of farmers, as it was already noted, continued to use oxen for heavy work in the field (plowing, transporting grain from the field, etc.). Under unsatisfactory housing conditions, their horses were simply unable to cope with such loads. Therefore horsepower was used primarily to treat land after plowing, working with a thrashing machines, light transportation, etc. (Bystrickij, 1889: 203).

\section{Areas of state support}

As we can see, the limit of both material resources and scientific knowledge on the maintenance and development of horses had a negative impact on the development of the industry. The peasants, who, in fact, only after 1861 began to engage in farming, have not yet formed a certain "culture" of farming in both agriculture and animal husbandry. In this situation, in order to overcome the crisis of horse breeding, which became very obvious in the early $1860 \mathrm{~s}$, the government took a number of incentive measures.

It should be noted that the horse breeding industry has been permanently under the protection of the state throughout the nineteenth century. The "first wave" of state measures was observed in the second quarter of the $19^{\text {th }}$ century. It was aimed at popularizing horse breeding in landed estates. We will remind that in the sphere of the state interests there was a breeding of riding horses. And the South of Ukraine has long been an important supplier of this mobile resource for cavalry. Therefore, in the 1830s and 1840s, the Simferopol Horse Factory and military horse factories under the Cavalry Districts of the military settlement in the Kherson Region were established here (Dubenskij, 1903: 239). In addition, there were state zemstvo connecting stables with mobile points, the first of which appeared in Ekaterinoslav and Kherson provinces. In the middle of the $19^{\text {th }}$ cent., from 50 to 100 thoroughbred stallions of various colors were kept here at public expense. Despite the promotion of horse breeding in this way 
and free services, local landowners and breeders seldom turned to these institutions - from 50 to 100 cases per year (Skalkovskij, 1853: 378-379). Therefore, over the next decades, the number of riding factories in southern Ukraine declined. First of all, this was due to the fact that in the process of formation of the capitalist economy, landlords and horse breeders faced the problem of increasing the cost of keeping horses. At the same time, the low purchase prices offered by the military (in fact, the only source of sales) were unprofitable and forced the owners to either choose more profitable industries, or at least switch to breeding trotters or workhorses, the prices of which covered the costs (Dubenskij, 1903: 239). The sale of riding horses from the peninsula of the Tavriya province was virtually impossible due to the distance from the roads ${ }^{3}$. As a result, the commission appointed in 1865 stated in general the absence of specialized factories for breeding riding horses in the Tavriya province.

So absence of expectations from the government explained the results of economic unreasonableness rather than by conviction correspondent of Main Department of State Horse Breeding collegiate adviser Ivanov, "probably indifference to new business from for horse breeders" . Instead, there is no doubt about his conclusion about the "sad" state of horse breeding in the region and the need for government intervention (Bojko, 2013: 111).

So "second wave" of government initiatives to encourage the horse breeding was observed in 1880-1890, which were controlled with the introduction of State Horse Breeding Committee or through local authorities. This time they aimed to improve the condition of agricultural horse breeding. After all, according to the observations of S. Urusov, "working breed, not surprisingly for the agricultural country, is in complete decline" (Urusov, 1911: 344). So counties were relied on primarily the task of promoting the improvement of breeds of local working horses that were used in farms, by organizing seedy settlements, rural stables and horse exhibitions.

In addition to the existing ones, in the 1890s the Tavriya State Stable was founded in Simferopol, as well as a network of county zemstvo stables with copulation stations. At the beginning of 189864 stallions were kept there, the value of which was determined at 800-1000 rubles, and some up to 2000 rubles! Among the represented breeds, specially brought from the St. Petersburg state horse breeding stable, were purebred English trotters, intended for racing and riding, as well as half-breeds, suitable for use on the farm and for transportation. In order to improve the quality of working horses, Russian thoroughbred trotters and small mountain horses were imported to farms (Svistula, 2015: 66).

Based on three stables, in the region for 15 years was equipped with 1,156 copulation stations, more than half of which were accounted for Kherson (Dubenskij, 1903: 240). Thus heads of departments of horsemanship tries to solve the dilemma of "Mohammed and the mountain," which, in their opinion, was the main obstacle of peasants' recourse to state factory stables. In addition, by prior arrangement with the owners, the best stallions of a certain breed were distributed at the village connecting points. Provision of services cost the population 2-3 rubles and sometimes free. Zemstvo also had the right to replenish stables. For example, Melitopol local authorities acquired 9 breeding stallions in 4 years, and 854 cases of copulation of peasant mares were recorded 5 .

During the 1 st decade of the $20^{\text {th }}$ cent. there was a certain revival in the work of the Tavriya state stable, which instilled in the initiators of the promotion of horse breeding a certain

\footnotetext{
3 State Archives in the Autonomous Republic of Crimea, Fund 77, Inventory 1, Case 268, Sheet 163 reverse-164

4 State Archives in the Autonomous Republic of Crimea, Fund 61, Inventory 1, Case 3, Sheet 3.

5 State Archives in the Autonomous Republic of Crimea, Fund 77, Inventory 1, Case 268, Sheet 4-9, 144.
} 
amount of optimism. In 1912 there had been already contained 112 stallions, operated 41 copulation stations, and the total number of calls has reached nearly $2500,78 \%$ of which from peasants ${ }^{6}$.

Traditionally steady demand for government stables was seen in Kherson, especially in Elisavetgrad district. Here during the last quarter of the $19^{\text {th }}$ cent. number of copulation stations increased in 3.7 times, the total number of applications - in 4,5 times. Interest in improving horse breeds has been growing steadily among the nobility (from $49.1 \%$ to $62.7 \%$ of appeals) and quite intensively among the peasantry (from $7.1 \%$ to $26.8 \%$ ) (Zertsalov, 1892: 28). Thus, landlords got an opportunity to save money, as farmers sought to improve work quality horses by changing oxen with them in households. However, in a large part of districts, state measures did not achieve the expected result: the connection points were closed due to lack of demand, and the peasants preferred to buy horses from the neighboring provinces. According to general estimates, less than $1 \%$ of mares in the Southern Ukrainian region were involved in the "services" of the stations, which obviously did not contribute to the development of local horse breeding (Dubenskij, 1903: 240). "How can we explain this attitude to copulation stations from peasants is a mystery", complained local veterinarian in an attempt to explain the age-old peasant conservatism?

Analyzing government steps to improve the state of horse breeding, you cannot keep on with a focus organizing horse races and exhibitions. Horse racing, understandably, focused on encouraging breeding for herd horsemanship of wealthy owners. In Kherson, Ekaterinoslav and Simferopol they were arranged at public expense since 1829 and brought the owners of the horses-winners money as a reward, which in the middle of the $19^{\text {th }}$ century was, for example, from 500 to 1500 rubles (Skalkovskij, 1853: 378). To organize equestrian exhibitions local authorities saw a way to socialize horse breeding, expand opportunities to get acquainted with the breeds of local horses and creating way to purchase horses for the cavalry. Because of geographical distancing and the lack of a developed transport infrastructure both farmers and landowners were deprived of the possibility to demonstrate and sell their horses in other regions $^{8}$. Accordingly, with the permission of the State Horse Breeding Committee initiative and funds for rural bodies at the turn of $19^{\text {th }}-20^{\text {th }}$ cent. equestrian exhibitions were held in the region every year. It is noteworthy that both riding and working breeds were presented among the exhibition specimens.

Assessing the value of exhibitions for the development and promotion of horse breeding business, known horseman knyaz S. Urusov noted that their success is ensured only by the presence of an interest in people to the field, not bureaucratic desire to "report" on the implementation. "Where there is chronic shortage of fodder, where there are no sufficient pastures, there it is impossible to improve, there is no horsemanship, and so there are useless exhibitions", he wrote (Urusov, 1905: 31).

As we can see, government measures have obviously not led to qualitative changes in the region's horse breeding. Quantitative development of industry explained only by growth of working needs of farms, because most farmers considered it "as a luxury because of questionable profitability and expensive maintenance" of horses (Bystrickij, 1889: 202). Therefore, the hopes for qualitative changes and comradeship of the industry were placed primarily on local

6 State Archives in the Autonomous Republic of Crimea, Fund 77, Inventory 1, Case 301, Sheet 49, 65-66.

7 State Archives in the Autonomous Republic of Crimea, Fund 62, Inventory 3, Case 232, Sheet 249-250.

8 State Archives in the Autonomous Republic of Crimea, Fund 77, Inventory 1, Case 268, Sheet 163 reverse- 164 . 
landowners: nobles, military, German colonists, who set up horse factories in their estates rather through "subjective enthusiasm" than economic feasibility.

\section{Trade in horses and pricing}

The degree of commoditiness of agricultural sectors in the formation of market relations was an important indicator of their development. Let's see how the process of horse breeding was realized in the South of Ukraine. Undoubtedly, with the growth of the population and the number of peasant farms, the priority of the use of horses in agriculture contributed to this. However, peasant horse breeding was focused on obtaining a working horse to meet economic needs. Horses were not bred for sale, so this industry (unlike, for example, merino sheep) did not become entrepreneurial. The trade component was only the surplus of cattle on the farm, which had no holiday trade.

Horse trading took place between the local populations and encompassed other Russian provinces (Merder, 1878: 8; Mel'nikova, 2017: 42-43). Bulk sales of horses were carried mostly by direct owner - horsemen, peasants, in some cases, intermediaries as Gypsies, Jews, and peasants. Among the major forms of trafficking - firstly urban, secondly market (day markets, rural markets) and fairs - the last was the most common, as was available for all population groups. About $80 \%$ of fair trade occurred in rural locations (Kandelaki, I., 1914: 8; Denisov, 1911: 15-17).

The most active fair trade was held in June and September. The impact on trade was carried out by weather and state of roads - main routes of connection in the $19^{\text {th }}$ cent. The most profitable period for sale of horses was consider summer and autumn, because horses had the most attractive inventory thanks to fresh feed and warm dry weather. Only in July-August the number fairs became much lower, which was associated with the beginning of rural agricultural activities, which, obviously, were not without horses.

Most of the population fairs, where horses purchase/sell occurs, were held in Elisavetgrad and Novomyrhorod (Kherson province), in Ekaterinoslav, colonies Eynlahe, Novomoskovsk, Bakhmut (Ekaterinoslav province), Kakhovka, Melitopol and Nogai (Tavriya province) (Skalkovskij, 1853: 377; Markov \& Dubenskij, 1903: 254-259). They differed in time, number, breeds and purpose of horses, regional differentiation in the supply and sale of horses, and so on. As a rule, at the largest fairs for sale were from 400 to 1 thousand horses; on smaller, respectively, - from 100 to 400 heads. Exceptions were fair of counties Tavriya province, where they brought herds of horses from surrounding counties of neighbouring provinces, as well as the Don region and the Black Sea (Chornomorskyi) province. So here the total number was measured in several thousand, reaching up to 10 thousand heads (Dubenskij, 1903: 257; Glavnoe Upravlenie Konnogo Zavodstva, 1884: 114). Regions supplying horses in Kherson and Ekaterinoslav fairs were much wider and supplemented by Poltava, Kharkiv, Kyiv, Kursk, Voronezh, provinces, Kuban, etc.

As a rule, most fair were specialized and subsequent to the sale of working horses, so the buyers were mostly farmers. In addition, harnessed horses were in demand, and riding repair horses were in low demand.

The only fair that gathered breeders from around the region and where the factory trotting thoroughbred horses were taken to sell, were held in Elisavetgrad district (Dubenskij, 1903: 258-259). In addition, only here there were purchases of horses for export to Austria and Romania, which were carried by cavalry repairmen (Glavnoe Upravlenie Konnogo Zavodstva, 1884: 132). 
Important significance played trade fairs in Novomoskovsk district (Glavnoe upravlenie Gosudarstvennogo Konnozavodstva, 1867: 44). For example, Pereschepynskyy fair gained popularity through prime location, because it was organized at the intersection of three trade routes: 1) from Voronezh and Kursk provinces to Yekaterinoslav; 2) from the Don and the Kuban through Ekaterinoslav to the Bessarabian province and Romania; 3) from Poltava province to fairs in neighbouring provinces (Dubenskij, 1903: 255). Usually purchases were carried out there of Don riding horses for Army cavalry. Purchased in Petropavlovsk fair riding horses were supplied to the Border Guard Service and the Romanian repairmen. Despite the fact that traditionally local fairs and factories remained a source of supply of riding horses for cavalry troops, during the study period championships were won by other regions, including Don (Mel'nikova, 2017: 49; Markov \& Dubenskij, 1903: 253).

Pricing in the horse trade was influenced by many factors. As a rule, in large holdings the supply of cattle with fodder did not depend on the yield of a certain year, so the owners did not sell horses due to food shortages, but on their own initiative. Therefore, the value of landowners' horses was determined solely by quality indicators. While the value of peasant horses did not depend on their "marketable appearance", but on the yield of a certain area and the owner's ability to feed cattle. "For the availability of feed stock, excess cattle farm was not for sale, but if the food is not enough, then all were sold", noted contemporaries (Zertsalov, 1892: 30). For example, the average cost of a horse in Elisavetgrad district in the harvest year of 1887 was 30-50 rubles, and in the barren year of 1889 it fell to 15-20 rubles. In the worst case, so that the horse simply did not die of starvation, the peasant had to give it for 6 rubles (mostly for slaughtering on a leather mill). Highest price for horses were observed in the spring, which was caused by seasonal demand of masters in traction force to perform agricultural work. If, for example, in the spring the horse could be bought for 57 rubles, then in the fall the price dropped to 46 rubles (Blioh, 1876:163).

Undoubtedly, an important factor in pricing was demand. For example, in times of crisis for horse in 1860 s at Petropavlivka fair in Ekaterinoslav among three thousand sale horses only 100 were purchased, and therefore the prices were relatively low - from 10 to 35 rubles. At the Uspensk fair (Ekaterinoslav province) out of 350 horses only 50 were sold on average for 25 rubles (Pamyatnaya knizhka Ekaterinoslavskoj gubernii na 1867 god, 1867: 123, 131). Nice horses, which cost up to 100 rubles, were not bought at all. In such circumstances, there was very popular exchange of horses among Gypsies, Jews and peasants, with compulsory currency surcharge - "pridacha"(addition). Inthe Spaso-Preobrazhensk fair it was noted that "currently trading of horses has fallen": herds of horses were not exhibited for sale, and the owners or dealers showed up to 5 horses which were sold on average for 20 rubles. (Pamyatnaya knizhka Ekaterinoslavskoj gubernii na 1867 god, 1867: 123-124). There were cases when they were not bought at all.

Since 1880 in parallel with the stabilization of the horsemanship in region, trade was increasing, as reflected primarily in growing prices and demand for horses.

In should be noted that the trend of growing prices was characteristic of animal husbandry development in general, so the rise in prices on the horses was in proportion to the price of large cattle, sheep, and pigs and so on. Since the 1910s, due to the increase in the number of peasant farms in European Russia, the problem of stagnation of agricultural horse breeding has again become acute for the state. Main State Horse Breeding Committee created a "special interdepartmental committee of horse breeding affairs", whose members prepared a "massive improvement project of horse breeding in country". The way out of this situation was seen by manufacturers especially in improving the quality of local breeds. However, 
given the extremely consumerist attitude to horse, which for decades formed at peasants societies, competent experts in this field evaluated these measures very pessimistic. "Degeneration of peasantry horse, as stressed by S. Urusov, is observed everywhere in Russia and is progressing almost at the same rate everywhere" (Urusov, 1905: 25). Given the lack of funds, shortage of pasture and feed, all zootechnical efforts to improve productivity of peasant working cattle were doomed to failure. Final blow to this industry, as well as private entities in general, had been dealt by notorious revolutionary events of 1917-1920 years.

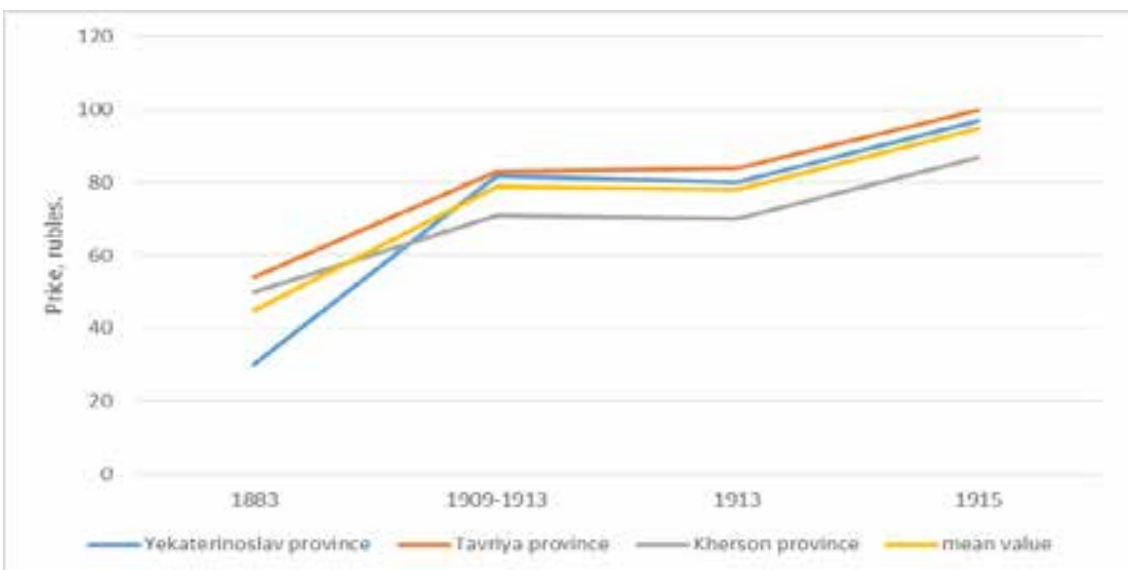

Graph 5. Dynamics of price increases on the horses in the South Ukrainian provinces

Source: Departament Zemledeliya i Selskoj Promyshlennosti, 1884; Glavnoe Upravlenie zemleustrojstva i zemledeliya, 1916: 28-29

\section{Conclusions}

Thus, horse breeding in the South of Ukraine after 1861 acquired a "peasant" (by social status of owners) character and was marked by agricultural orientation. The increase in the number of horses in the region was explained by the growth of the population and peasant farms. The development of horse breeding was facilitated by the growth of the share of working horses in peasant farms, which was manifested in the expansion of the range of their exploitation. Therefore, we can state that the development of the industry took place extensively in accordance with the growth of production needs and the number of agricultural centers in the region. Despite the favorable natural and climatic conditions, the presence of stable demand for horses, this industry did not receive entrepreneurial orientation, so it could not claim the championship among others. Trade of working horses (and, hence, their pricing), despite the presence of stable demand among the peasants, remained excessively situational and limited to the domestic market. Wealthy farmers tended to engage in those types of farming that yielded the fastest profits and were less costly to invest.

Indeed, keeping horses was too costly for the average peasant. A purely pragmatic approach to the use of horses as "livestock", inadequate housing conditions, uncontrolled reproduction of livestock, disease and theft of horses did not contribute to the productivity of the industry. Peasant farming was in its infancy, and most peasant farms had no marketable orientation at all. Under such conditions, it is obvious that the peasants were unable to ensure the 
quality development of horse breeding without state support. It is worth of positively assessing the government's efforts to improve the quality characteristics of peasant horses, which consisted of creating state stables with numerous connecting points in southern Ukraine, organizing exhibitions to increase zootechnical awareness, forming a "culture of horse breeding" among the population and more. However, the deterioration of the socio-political and economic situation, the First World War, the revolutions and the collapse of the Russian Empire and the establishment of Soviet power in Ukraine put an end to peasant farming for many decades. After gaining independence in 1991, Ukraine began complex processes of entrepreneurship in the agricultural sector of the economy. Therefore, the analysis of the specifics, problems and prospects, achievements and failures in the development of leading agricultural industries in the South of Ukraine in the second half of the $19^{\text {th }}-$ early $20^{\text {th }}$ cent. can be useful for building your own strategy for the development of agricultural production at the present stage.

\section{References}

Blioh, I. S. (1876). Issledovaniya po voprosam, otnosyashimsya k proizvodstvu torgovli i peredvizheniyu skota $i$ skotskih produktov $v$ Rossii $i$ za granicej [Research on issues related to the production of trade and the movement of livestock and livestock products in Russia and abroad: graphic images]. Sankt-Peterburg: Tipografiya M. O. Volfa [in Russian]

Bojko, V.V. (2013). Razvitie konevodstva i konnozavodstva v Tavricheskoj gubernii vo vtoroj polovine 19 - nachale 20 veka [The development of horse breeding and horse breeding in the Tauride province in the second half of the 19 - early 20 century]. Nauchnye vedomosti. Seriya Istoriya. Politologiya. Ekonomika. Informatika, 22 (165), 110-114. [in Russian]

Bystrickij, N.S. (Comp.) (1889). Pamyatnaya kniga i Adres-kalendar Ekaterinoslavskoj gubernii na 1889 god [Commemorative book and Address-calendar of the Ekaterinoslav province for 1889]. Ekaterinoslav: Tipografiya Gubernskogo Pravleniya. [in Russian]

Centralnyj Statisticheskij Komitet Ministerstva Vnutrennih Del (1891). Voenno-konskaya perepis 1888 goda [Military horse census of 1888]. Sankt-Peterburg: CSK MVD. [in Russian]

Centralnyj Statisticheskij Komitet Ministerstva Vnutrennih Del (1894). Voenno-konskaya perepis 1891 goda [Military horse census of 1891]. Sankt-Peterburg: CSK MVD. [in Russian]

Centralnyj Statisticheskij Komitet Ministerstva Vnutrennih Del (1901). Svedeniya o kolichestve skota $v 1900 \mathrm{~g}$. Po dannym volostnyh pravlenij i uezdnoj policii [Information about the number of livestock in 1900: According to the volost boards and the district police]. Sankt-Peterburg: Tipografiya AO Pechatnogo Dela E. Evdokimova [in Russian]

Centralnyj Statisticheskij Komitet Ministerstva Vnutrennih Del (1914). Voenno-konskaya perepis 1912 g. [Military horse census of 1912]. Petrograd: CSK MVD. [in Russian]

Chirvinskij, N. P. (1902). Chastnoe skotovodstvo i skotovrachevanie [Private cattle breeding and cattle treatment]. In Uchebnik skotovodstva i skotovrachevaniya dlya nizshih selskohozyajstvennyh uchebnyh zavedenij [Textbook of cattle breeding and cattle treatment for lower agricultural schools]. (Vol. 2). St. Petersburg: A.F. Devrien. [in Russian]

Denisov, V. I. (1911). Yarmarki [Fairs]. Sankt-Petersburg: V.O. Kirshbaum. [in Russian]

Departament Zemledeliya i Selskoj Promyshlennosti (1884). Svedeniya za osennij period $i$ obshij obzor goda. In 1883 god v selskohozyajstvennom otnoshenii po otvetam, poluchennym ot hozyaev [1883 in the agricultural relation according to the answers received from the owners]. (Issue 3). Sankt-Peterburg: Tipografiya V. Bezobrazova i $K^{\circ}$. [in Russian]

Dubenskij, D. N. (1903). Konevye sredstva Evropejskoj Rossii: Obsledovanie sovremennogo sostoyaniya konnozavodstva i konevodstva gubernij Evropejskoj Rossii s istoricheskim 
ocherkom [Horses means European Russia: A survey of the current state of horse breeding and horse breeding in the provinces of European Russia, with a historical sketch]. Sankt-Peterburg: Glavnyj shtab. [in Russian]

Giber-von-Greifenfels, A.W. (1897). Konevodstvo i konnozavodstvo v imeniyah naslednika Falc-Fejna Tavricheskoj gubernii Dneprovskogo uezda. [Horse breeding in the estates of the heir of Falz-Fein of the Tavriya province of the Dniprovsky district]. Odessa: Tipografiya Ganperina i Shvejcera. [in Russian]

Glavnoe upravlenie Gosudarstvennogo Konnozavodstva [Main Directorate of State Horse Breeding,] (1867). Pamyatnaya knizhka po Glavnomu upravleniyu gosudarstvennogo konnozavodstva na 1867 god [Commemorative Book of the Main Directorate of State Horse Breeding for 1867]. St. Petersburg: Tipografiya E. Metciga [in Russian].

Glavnoe Upravlenie Konnogo Zavodstva (1884). Konskaya perepis 1882 goda [Horse Census of 1882]. Sankt-Peterburg: Tipografiya Mesnika i Rimana [in Russian]

Glavnoe Upravlenie zemleustrojstva i zemledeliya (1916). Mestnye ceny na polevye proizvedeniya, skot i produkty zhivotnovodstva : srednie za pyat let, 1909-1913 gg. i v 1915 godu. In 1915 god $v$ selskohozyajstvennom otnoshenii po otvetam, poluchennym ot hozyaev [1883 god v selskohozyajstvennom otnoshenii po otvetam, poluchennym ot hozyaev]. (Issue 6. Part 2). Petrograd: Tipografiya V. F. Kirshbauma [in Russian].

Kandelaki, I. (1914). Rol yarmarok v russkoj torgovle [The role of fairs in Russian trade]. Sankt-Petersburg: Redaktsiya periodicheskih izdaniy Ministerstva finansov. [in Russian]

Kaufman, A. A. (1917). Voprosy ekonomiki i statistiki krestyanskogo hozyajstva [Issues of economics and statistics of the peasant economy]. (Issue 1). Moscow: Izdanie G.A. Lemana $i$ S.I. Saharova. [in Russian]

Kherson Provincial Statistical Committee. (1863). Materialy dlya geografii i statistiki Hersonskoj gubernii. In Trudy Hersonskogo gubernskogo statisticheskogo komiteta [Proceedings of the Kherson Provincial Statistical Committee]. (Book 1. Part 1). Kherson: Gubernskaya tipografiya. [in Russian]

Markov (Ed.), Dubenskij, D. N. (Comp.) (1903). Konevye sredstva Evropejskoj Rossii: Obsledovanie sovremennogo sostoyaniya konnozavodstva i konevodstva gubernij Evropejskoj Rossii, s istoricheskim ocherkom) [Horses means European Russia: A survey of the current state of horse breeding and horse breeding in the provinces of European Russia, with a historical sketch]. Sankt-Peterburg: Voennaya tipografiya [in Russian]

Mel'nikova, D. A. (2017). Konskaya torgovlya v Rossijskoj imperii vo vtoroj polovine XIXnachale $X X v v$. [Horse-trading of Russian Empire in the second half of XIX-at the beginning of the XX c.], History of everyday life, 42-51 [in Russian]. URL: https://cyberleninka. ru/article/n/konskaya-torgovlya-v-rossiyskoy-imperii-vo-vtoroy-polovine-xix-nachale-xx-vv (accessed May 12, 2021)

Merder, I. K. (1878). Spisok chastnyh konskih zavodov v Rossii [Collection of information about the trade in horses and a list of horse farms in Russia]. Sankt-Peterburg: Tipografiya E. Metciga [in Russian]

Ostrovskij, A.V. (2014). Zhivotnovodstvo Evropejskoj Rossii v konce XIX-nachale XX v. [Livestock raising in European Russia at the end of the 19th - beginning of the 20th century]. Sankt-Peterburg: OOO "Poltorak" [in Russian]

Pamyatnaya knizhka Ekaterinoslavskoj gubernii na 1867 god [Commemorative book of the Yekaterinoslav province for 1867] (1867). (Part 2). Ekaterinoslav: Tipografiya Gubernskogo pravleniya. [in Russian] 
Skalkovskij, A.A. (1853). Opyit statisticheskogo opisaniya Novorossiyskogo kraya [Experience of statistical description of the Novorossiysk region]. (Part 2). Odessa: Tipografiya Frantsova i Nitche. [in Russian]

Svistula, O. V. (2015). Koniarstvo na Pivdni Ukrainy: istorychnyi ekskurs [Horse breeding in the South of Ukraine: a historical excursion]. Tvarynnytstvo ta tekhnolohii kharchovykh produktiv, 207, 63-73. URL: http://journals.nubip.edu.ua/index.php/Tekhnologiya/article/ view/5586/5496 (accessed May 5, 2021). [in Ukrainian]

Urusov, S. P. (1911). Kniga o loshadi [A book about a horse]. (Vol. 1). Sankt-Peterburg: Russkoe knizhnoe tovarishestvo Deyatel. [in Russian]

Urusov, S. P. (1905). Krestyanskoe konevodstvo, ego sovremennoe sostoyanie i puti k uluchsheniyu [Peasant horse breeding, its current state and ways to improve]. In Trudy oblastnogo sezda po zhivotnovodstvu s 14 po 24 sentyabrya 1903 g. v gorode Harkove [Proceedings of the regional congress on animal husbandry from 14 to 24 September 1903 in the city of Kharkov]. Kharkov: Centralnaya Hromo-Tipo-Litografiya "Varshavchik". (Vol. 2). [in Russian]

Verner, K. A. (Ed.) (1889). Sbornik statisticheskih svedenij po Tavricheskoj gubernii. Pamyatnaya knizhka Tavricheskoj gubernii [Collection of statistical data on the Tavriya province. Memorable book of the Tauvriya province]. (Vol. 9). Simferopol: Tipografiya gazety "Krym”. [in Russian]

Veterinarnoe upravlenie Ministerstva Vnutrennih Del (1915a). Predvaritelnye dannye o chislennosti domashnih zhivotnyh $v$ Rossijskoj imperii v $1913 \mathrm{~g}$. [ Preliminary data on the number of domestic animals in the Russian Empire in 1913]. Petrograd: MVD [in Russian]

Veterinarnoe upravlenie Ministerstva Vnutrennih Del (1915b). Predvaritelnye dannye o chislennosti i uboe zhivotnyh $v$ Rossijskoj imperii v $1914 \mathrm{~g}$. [Preliminary data on the number and slaughter of animals in the Russian Empire in 1914]. Petrograd: MVD [in Russian]

Volos, O.V. (2012). Z istorii pryvatnoho kinnozavodstva Khersonskoi hubernii (II polovyna 19 pochatok 20 stolittia) [From the history of private horse breeding in Kherson province (second half of the 19 - beginning of the 20 century]. Ukrainian peasant, 13, 99-102. [in Ukrainian] Zaderejchuk, A.A. (2010). Falc Fejny v Tavrii [Falz-Feins in Tavria]. Simferopol: Dolya. [in Russian]

Zertsalov, S.A. (1892). Stepnoe skotovodstvo v Novorossijskom krae, ego proshloe i nastoyashee [Steppe cattle breeding in the Novorossiysk region, its past and present]. Odessa: Slavyanskaya tipografiya N. Hrisogelos. [in Russian] 